\title{
Catchment versus Riparian Buffers: Which Land Use Spatial Scales Have the Greatest Ability to Explain Water Quality Changes in a Typical Temperate Watershed?
}

\author{
Minmin Song ${ }^{1,2}$, Yuan Jiang ${ }^{1,2, *}$, Qi Liu ${ }^{3}$, Yulu Tian ${ }^{4}$, Yang Liu ${ }^{2}$, Xia Xu ${ }^{2}$ and Muyi Kang ${ }^{1,2}$ \\ 1 Beijing Key Laboratory of Traditional Chinese Medicine Protection and Utilization, Faculty of Geographical \\ Science, Beijing Normal University, Beijing 100875, China; 201831051078@mail.bnu.edu.cn (M.S.); \\ kangmy@bnu.edu.cn (M.K.) \\ 2 State Key Laboratory of Earth Surface Processes and Resource Ecology, Faculty of Geographical Science, \\ Beijing Normal University, Beijing 100875, China; lykasaharajune@mail.bnu.edu.cn (Y.L.); \\ xuxia@bnu.edu.cn (X.X.) \\ 3 School of Environment, Beijing Normal University, Beijing 100875, China; liuq@mail.bnu.edu.cn \\ 4 College of Urban and Environmental Sciences, Northwest University, Xi'an 710127, China; \\ tianyulu0052@126.com \\ * Correspondence: jiangy@bnu.edu.cn; Tel.: +86-10-5880-6093
}

\section{check for} updates

Citation: Song, M.; Jiang, Y.; Liu, Q.; Tian, Y.; Liu, Y.; Xu, X.; Kang, M. Catchment versus Riparian Buffers: Which Land Use Spatial Scales Have the Greatest Ability to Explain Water Quality Changes in a Typical Temperate Watershed? Water 2021, 13, 1758. https://doi.org/10.3390/ w13131758

Academic Editor: Manuel

J. Rodriguez

Received: 25 May 2021

Accepted: 22 June 2021

Published: 25 June 2021

Publisher's Note: MDPI stays neutral with regard to jurisdictional claims in published maps and institutional affiliations.

Copyright: (c) 2021 by the authors. Licensee MDPI, Basel, Switzerland. This article is an open access article distributed under the terms and conditions of the Creative Commons Attribution (CC BY) license (https:/ / creativecommons.org/licenses/by/ $4.0 /)$.

\begin{abstract}
Identifying the multi-scale spatial relationship between land use and water quality is critical for determining the priorities and key areas of river management. To more accurately identify the scale effect of land-use patterns on water quality and quantitatively distinguish the difference in the impacts of land-use composition and configuration on water quality, we used 94 sites to extract the upstream catchment and riparian buffer zone with different widths. The results showed that the ability of land use variables with different buffer widths to explain water quality differed slightly from the ability of these variables at the catchment scale, and the joint explanatory ability of land use composition and configuration was greater than that of each individually. The patch density and landscape shape index of cultivated land, shrubland, and built-up land in the buffer area close to the water bodies were the main factors for the increase in the concentration of total nitrogen, nitrate nitrogen, total phosphorus, and suspended solids. As the width of the buffer increased, the role of the percent of land use increased. Our research indicates that water quality management needs to adopt a multi-scale perspective and focus on key local areas while coordinating at a broader scale.
\end{abstract}

Keywords: landscape ecology; multi-scale; riparian buffer zone; catchment; water quality; fragstats

\section{Introduction}

Due to the dual threats of climate change and human activities, most river ecosystems in the world are currently being damaged to varying degrees [1-3]. Land use has been proven to be one of the most significant human activities affecting river ecosystems [4,5]. A large amount of industrial and urban domestic wastewater discharge in basins, agricultural production, grassland destruction, deforestation, and other activities have led to ecological and environmental problems such as destruction of river habitats, deterioration of water quality, and degradation of aquatic community structure [6-8]. The Global Risks Report 2020 also pointed out that water resources and related environmental problems were one of the most serious current crises and that water quality problems were particularly significant (World Economic Forum, WEF) [9]. Therefore, identifying the relationship between land use and water quality is of great significance to improving the water quality of rivers.

The relationship between land use and water quality is very sensitive to scale changes [10-12]. Many studies have shown that the impact of land use on water quality varies from the riparian zone to the catchment or other spatial scales [13,14]. As a land-water ecotone, the riparian zone is the last line of defense for river water quality protection $[15,16]$ and plays 
an important role in intercepting pollutants, improving water quality, and maintaining habitat diversity for river ecosystems $[17,18]$. The difference in the relationship between land use and water quality caused by various spatial scales is a challenge for current research [19]. Existing studies disagree over the spatial scales that have the strongest correlation between land use and water quality in a specific watershed [11,20,21], and this disagreement is mainly caused by the uniqueness of each basin [7]. At the same time, confusion among related concepts and irregular definition methods at different scales are also important reasons that it is difficult to compare similar studies [22]. Therefore, the accurate identification of the contribution of land use to multi-scale impacts on water quality still requires further scientific examination.

Previous studies have shown that land-use patterns (mainly in terms of the composition and spatial configuration of land use/cover types) play an important role in the formation, release, absorption, and interception of pollutants, which in turn affect the water quality of rivers $[23,24]$. Land use configuration refers to the spatial distribution of land use patches and their relationships to one another [25], which affects the exchange of water flows on land surfaces among different land use patches [26]. In recent years, research on the impact of land-use configuration on water quality has gradually attracted attention, and a landscape index has become an important analytical indicator [27]. Studies have shown that utilizing the landscape indices used to describe land use configuration may be better than using the proportion of each land use patch type (land use composition) to predict water quality changes $[13,19,28,29]$. However, due to the randomness and collinearity of landscape indices selection [30], the difference in the explanatory power of land use composition and configuration in terms of river water quality is uncertain. A lack of understanding of this relationship will restrict the formulation and implementation of specific control measures by watershed managers [31]. What is gratifying is that with the development of multivariate statistical techniques, gradient analysis methods have been introduced to quantitatively distinguish the contribution rates of different land-use variables to the spatial differentiation of water quality [12]. Therefore, it is urgent to further explore how to quantify the impact of land use composition and configuration on water quality and determine the contribution of major land-use variables to the water quality of rivers [11].

The Luanhe River basin in China plays an important role in the "Diversion Project from Luan-he to Tianjin", several major tributaries of the upper and middle streams of the Luanhe River basin flow into the mainstream, eventually draining into the Daheiting and Panjiakou reservoirs, and the starting point of the Project is Daheiting reservoir, which provides valuable water resources for Tianjin and Tangshan. Great changes in land use have occurred due to urban expansion and agricultural development [32,33], which result in latent dangers to the water supply. Therefore, it is of great significance to explore the multi-scale relationship between land use and water quality in this basin to improve water quality and the healthy development of aquatic ecology. The objectives of this study were threefold: (1) to reveal the relationship between land use patterns and river water quality at different spatial scales; (2) to identify the main land-use variables that affect water quality at different spatial scales; and (3) to distinguish the differential impact of land use composition and spatial configuration on water quality changes.

\section{Methods and Materials}

\subsection{Study Area}

The Luanhe River basin originates in the Bayantugur Mountains in Fengning County, Hebei Province, in North China between $115^{\circ} 32^{\prime}-118^{\circ} 53^{\prime} \mathrm{E}$ and $40^{\circ} 11^{\prime}-42^{\circ} 45^{\prime} \mathrm{N}$ and covers an area of $3.6 \times 10^{4} \mathrm{~km}^{2}$ (Figure 1). This area is influenced by a typical temperate monsoon climate and has had an average annual atmospheric temperature of $6.1{ }^{\circ} \mathrm{C}$ and a mean annual precipitation of $444.1 \mathrm{~mm}$ over the last 30 years (http:/ / data.cma.cn, accessed on 16 August 2017). The mean annual average runoff from the study area is $39.3 \times 10^{8} \mathrm{~m}^{3}$, approximately $66 \%$ of which is from precipitation from June to September [33]. Brown 
earth, cinnamon soils, and Castanozems account for more than $80 \%$ of the total area of the basin, with poor corrosion resistance and high nitrogen content. The predominant land use type is shrubland, which occupied $41.75 \%$ of the basin in 2016 . Furthermore, its average slope is the largest among all land use types (Table 1). The crops were mainly corn, rice, and soybean, and approximately $3.8 \times 10^{6}$ inhabitants lived in the study area in $2016[34,35]$.

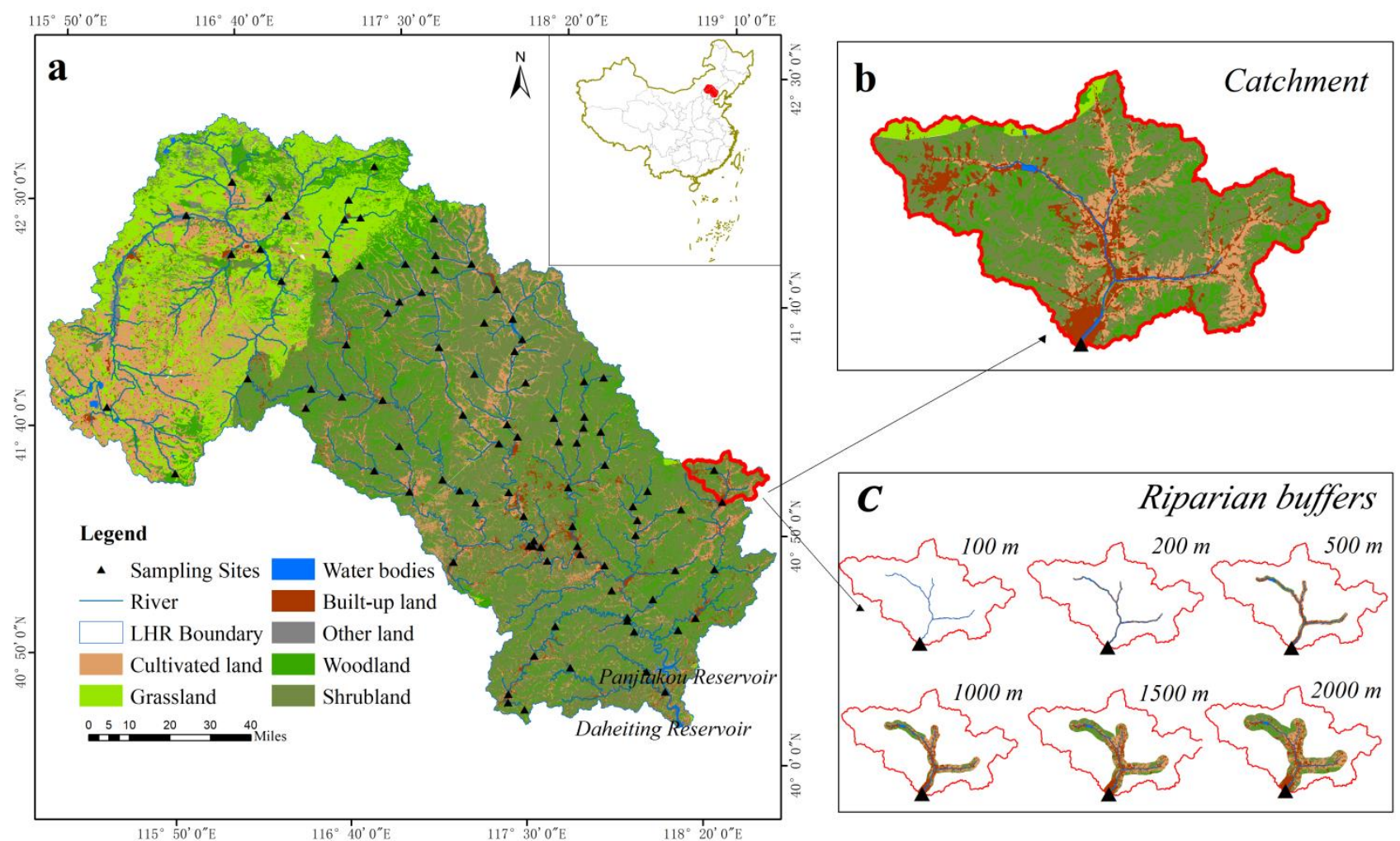

Figure 1. Location and characteristics of the study area: (a) the location of the 94 sampling sites in the Luanhe River basin and the land use types; (b) catchment (entire upstream catchment above the sampling site); and (c) riparian buffer with different widths.

Table 1. Average slope of main land use types.

\begin{tabular}{cccccc}
\hline Land Use Types & Cultivated Land & WoodLand & ShrubLand & GrassLand & Built-Up Land \\
\hline Average slope $\left(^{\circ}\right)$ & 9.20 & 19.07 & 19.59 & 8.66 & 9.55 \\
\hline
\end{tabular}

\subsection{Water Sampling and Parameter Measurements}

Considering that the precipitation in the study area is concentrated from June to August and that nonpoint source pollution also mainly occurs during this period, water samples were collected in July 2017 [33]. Based on the principle of stratified sampling and the uniformity of spatial distribution, traffic accessibility, and others, a total of 94 sampling sites were established in the study area, covering various types of land uses and major tributaries in the basin. Water samples were collected based on the "Standard Methods for the examination of Water and Wastewater (version 4), 2002" [36], and 1 L plexiglass water collectors were used to collect water samples at the surface of the river (water depth at the center of the sampling point or $5 \mathrm{~m}$ from the bank at approximately $0.5 \mathrm{~m}$ ). Water samples were collected three times at each sampling site and mixed thoroughly. The mixed water samples were divided into two groups: one was the raw water sample without any treatment; the other water sample was filtered through precombusted $0.45 \mu \mathrm{m}$ glass fiber filters (WCN grade: Whatman GF/F filters, Maidstone, UK) for subsequent soluble substance analysis. A small amount of concentrated sulfuric acid $\left(\mathrm{H}_{2} \mathrm{SO}_{4}\right)$ was added to 
the two water samples for acid preservation. The filter was stored in a dark place protected from light and was used to determine chlorophyll a (Chla) and suspended solids (SS). The water sample bottle was immersed in a 1:10 hydrochloric acid solution for $24 \mathrm{~h}$, washed with distilled water, and dried; the glass cellulose film was pretreated at $450{ }^{\circ} \mathrm{C}$ for $6 \mathrm{~h}$. All samples were stored frozen at a low temperature and returned to the laboratory for indoor analysis in the shortest possible amount of time.

We analyzed 11 water quality parameters, including $\mathrm{pH}$, electrical conductivity (EC, $\mu \mathrm{s} / \mathrm{cm}$ ), dissolved oxygen (DO, $\mathrm{mg} / \mathrm{L})$, permanganate index $\left(\mathrm{COD}_{\mathrm{Mn}}, \mathrm{mg} / \mathrm{L}\right)$, 5-day biochemical oxygen demand $\left(\mathrm{BOD}_{5}, \mathrm{mg} / \mathrm{L}\right)$, total phosphorus $(\mathrm{TP}, \mathrm{mg} / \mathrm{L})$, total nitrogen $(\mathrm{TN}$, $\mathrm{mg} / \mathrm{L})$, ammonia nitrogen $\left(\mathrm{NH}_{3}-\mathrm{N}, \mathrm{mg} / \mathrm{L}\right)$, nitrate-nitrogen $\left(\mathrm{NO}_{3}-\mathrm{N}, \mathrm{mg} / \mathrm{L}\right)$, chlorophyll a (Chla, $\mu \mathrm{g} / \mathrm{L}$ ), and suspended solids (SS, $\mathrm{mg} / \mathrm{L}$ ). The water chemical analysis followed the national standard methods for examining water and wastewater in China [36].

\subsection{Quantification of Land Use Indicators}

The mainstream and catchment boundaries were extracted from a digital elevation model (DEM, ASTER GDEM V2) with a spatial resolution of $30 \mathrm{~m}$ using the ArcSWAT extension module, which is the graphical user interface of the SWAT (Soil and Water Assessment Tool) model on the ArcGIS platform (ESRI Company, Redlands, CA, USA) [37]. The land use data were derived from 2016 Landsat 8 satellite images, downloaded from https://glovis.usgs.gov/ (accessed on 1 August 2018). Images were preprocessed by ENVI 5.3 software (Exelis Visual Information Solutions, Boulder, CO, USA) for radiometric calibration, atmospheric correction, and image sharpening. The processed images were used to create a land-use map through a supervised maximum likelihood classification, and the land uses were classified into 22 types. The overall accuracy of each land use type was above $90 \%$, and the kappa coefficient was above $85 \%$. Land uses were reclassified into seven categories according to the needs of the study: (1) cultivated land (cul), including paddy fields and dry land; (2) woodland (woo), including sparse wood and other forests; (3) shrubland (shr), including bushes and orchards; (4) grassland (gra), including pastures and grass communities; (5) water bodies (wat), including rivers, wetlands, and reservoirs; (6) built-up land (bui), including urban, rural residential areas and other infrastructure; and (7) other land (oth). The proportions of cultivated land, woodland, shrubland, grassland, water bodies, built-up land, and other land in the study area were $17.97 \%, 16.04 \%, 41.75 \%$, $17.28 \%, 0.51 \%, 3.94 \%$, and $2.50 \%$, respectively (Figure 1 ).

The land-use variables that were considered to have a great impact on water quality changes in previous studies were selected [38]. We mainly focused on the relationship between land-use variables and water quality parameters at the class level, including the percent of landscape (PLAND), patch density (PD), landscape shape index (LSI), aggregation index (AI), and large patch index (LPI) [24]. In addition, patch density (PD), landscape shape index (LSI), contagion (CONTAG), and the Shannon's diversity index (SHDI) were calculated at the landscape level to understand the overall land-use characteristics at different scales [12]. It is worth noting that the purpose of our analysis of land-use variables was to link the size, shape, and connectivity of land use patches with specific impacts on ecological water processes rather than just to evaluate and quantify the index in isolation [39]. These metrics were calculated using FRAGSTATS 4.2 software expressed not only the proportion of land use but also the fragmentation of the land use, shape complexity, connectivity, and diversity [40].

Land-use variables were identified at multiple spatial scales (Figure 1), which were the catchment scale (entire upstream catchment above the sampling site) [13] and the scale of a riparian buffer with different widths $(100 \mathrm{~m}, 200 \mathrm{~m}, 500 \mathrm{~m}, 1000 \mathrm{~m}, 1500 \mathrm{~m}$, and $2000 \mathrm{~m})$. The riparian buffer widths were extracted and calculated in batches by Python scripts with the ArcPy site package (ArcGIS 10.3 License, ESRI Company, USA). 


\subsection{Statistical Analysis}

First, the Kolmogorov-Smirnov test was used to examine the normality of the water quality variables, and the $\log (x+1)$ transformation of the water quality variables were performed to meet the assumptions of normality before redundancy analysis (RDA). The land-use variables that greatly contributed to water quality $(p<0.05)$ were screened through stepwise regression analysis, RDA was performed for the analysis of the water quality and land-use patterns relationships, and Monte Carlo permutation $(n=499)$ was adopted to test the significance of the RDA results [41]. The cosine value of the angle between the arrow of the land-use variable and the arrow of the water quality variable in the RDA sequence diagram was positive, indicating that the relationship between the two was positively correlated, and the longer the arrow was, the stronger the correlation between the two variables [42]. Furthermore, variation partitioning analysis (VPA) was used to perform partial redundancy analysis on land-use composition and configuration indicators, decomposing the respective individual explanatory ability and joint explanatory ability of the land use composition and configuration for water quality changes [43]. Stepwise regression analysis was implemented in SPSS 20.0 software (IBM Company, Chicago, IL, USA), and both RDA and VPA were implemented in the CANOCO 5.0 program (Microcomputer Power Company, El Segundo, CA, USA).

\section{Results}

\subsection{Differences in Land Use Variables and Water Quality Characteristics}

For the land-use composition of the riparian buffer widths and catchment (Figure 2), the proportion of cultivated land and built-up land in the riparian zone showed a clear downward trend as the width of the buffer increased, while the changing trend for the area of woodland and shrubland had the opposite trend. Additionally, among the land use types, shrubland area accounted for the largest proportion and was the dominant land use type in the basin. The proportion of grassland, water bodies, and other land changed relatively little. For the land-use spatial configuration (Figure 3), the PD in the $100 \mathrm{~m}$ buffer was the largest. As the width of the buffer increased, the PD gradually decreased, and the $P D$ value of the $2000 \mathrm{~m}$ buffer was generally equal to the PD value of the catchment. The LSI and CONTAG both decreased slightly and then gradually increased as the width of the buffer increased, while the SHDI showed the opposite trend. From the overall change trend in land use, it can be seen that the land-use composition and configuration characteristics of the $2000 \mathrm{~m}$ buffer and catchment were relatively similar.

There were significant spatial differences in water quality in the study area (Figure 4). The spatial distributions of $\mathrm{COD}_{\mathrm{Mn}}, \mathrm{TP}, \mathrm{EC}, \mathrm{TN}, \mathrm{NH}_{3}-\mathrm{N}$, and $\mathrm{NO}_{3}-\mathrm{N}$ were quite different. Among them, the larger areas of $\mathrm{COD}_{\mathrm{Mn}}$ and $\mathrm{NH}_{3}-\mathrm{N}$ appeared in the farming-pastoral ecotone in the upper reaches of the basin. The larger areas of TP, EC, TN, and $\mathrm{NO}_{3}-\mathrm{N}$ were mainly distributed in the hilly areas in the middle and lower reaches of the basin, and the spatial distribution of the other water quality parameters was not significantly different. 


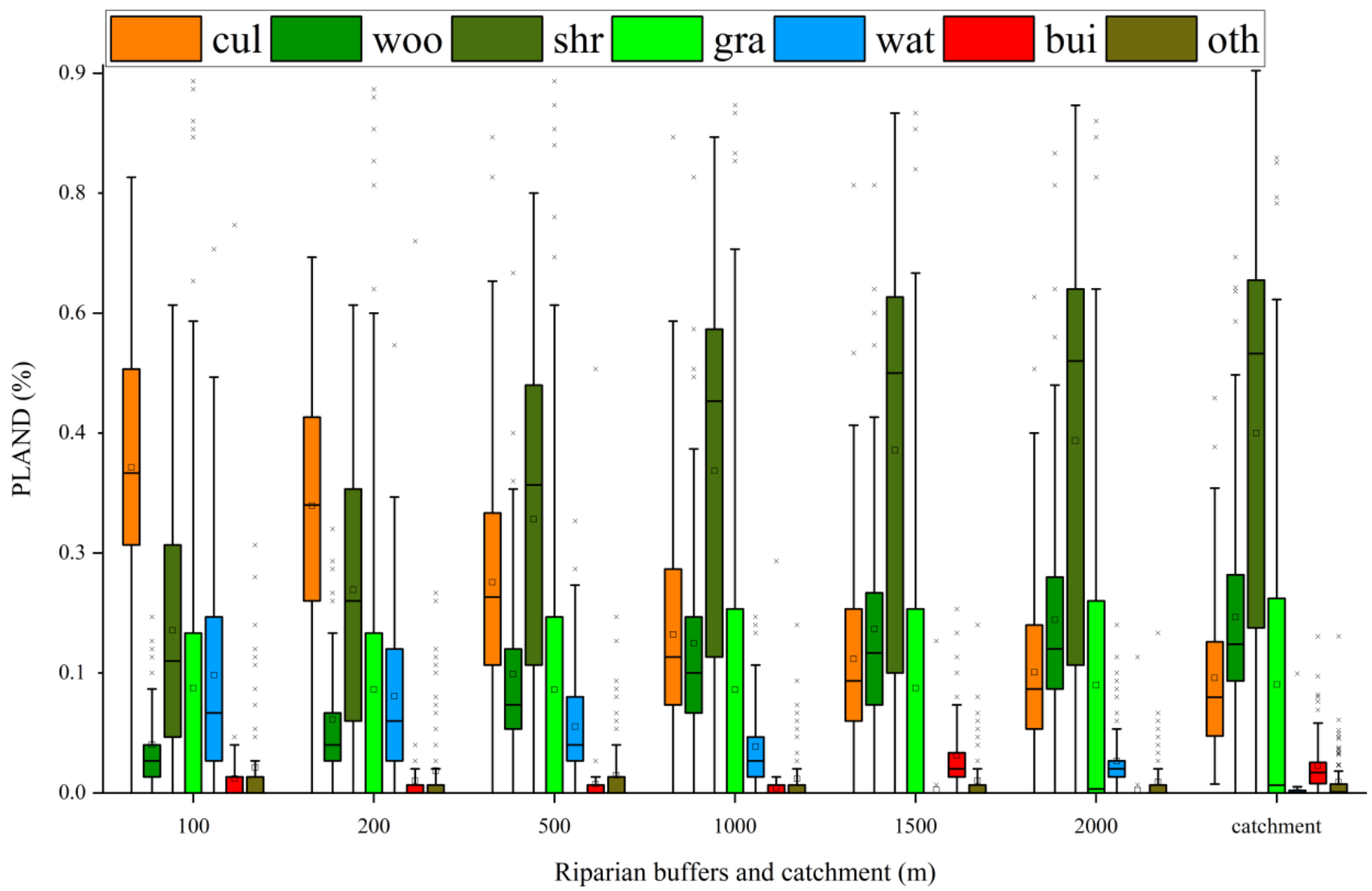

Figure 2. The variations in the land use composition of the riparian buffer widths and catchment. Land use types include the cultivated land (cul), woodland (woo), shrubland (shr), grassland (gra), water bodies (wat), built-up land (bui) and other land (oth).

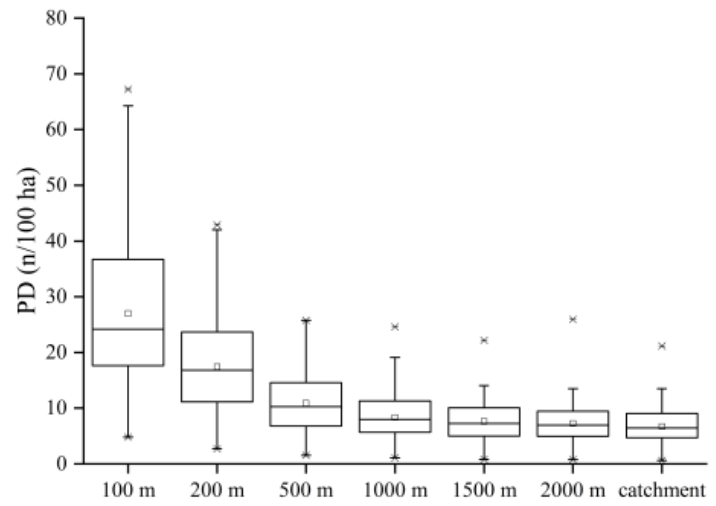

(a)

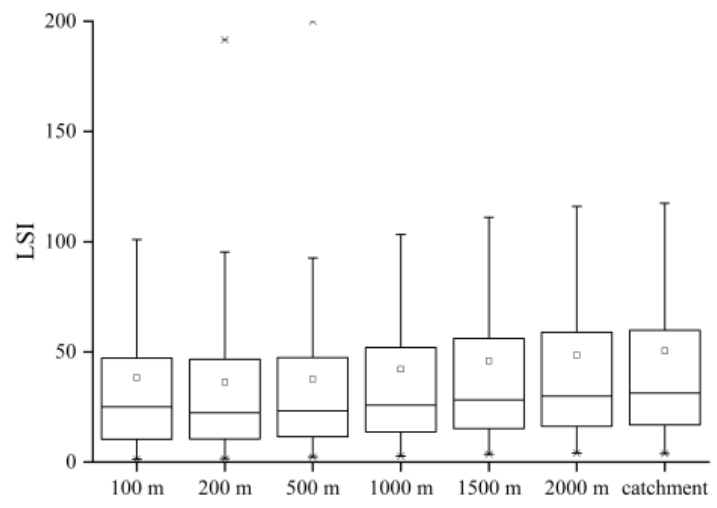

(b)

Figure 3. Cont. 


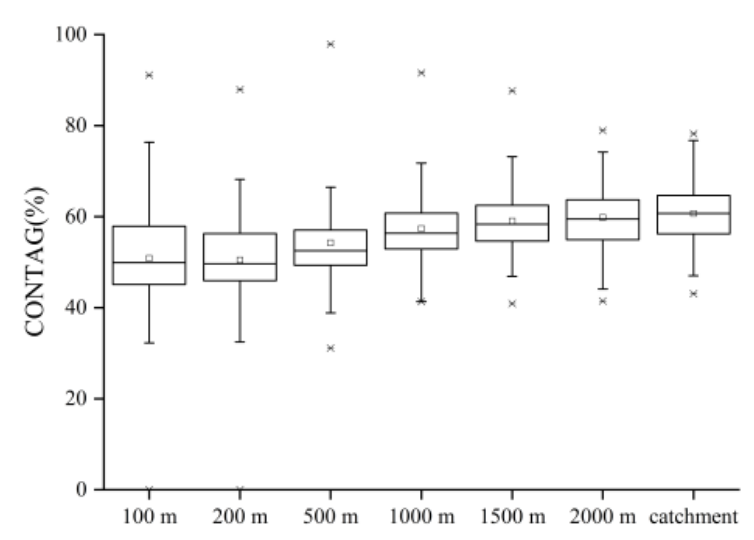

(c)

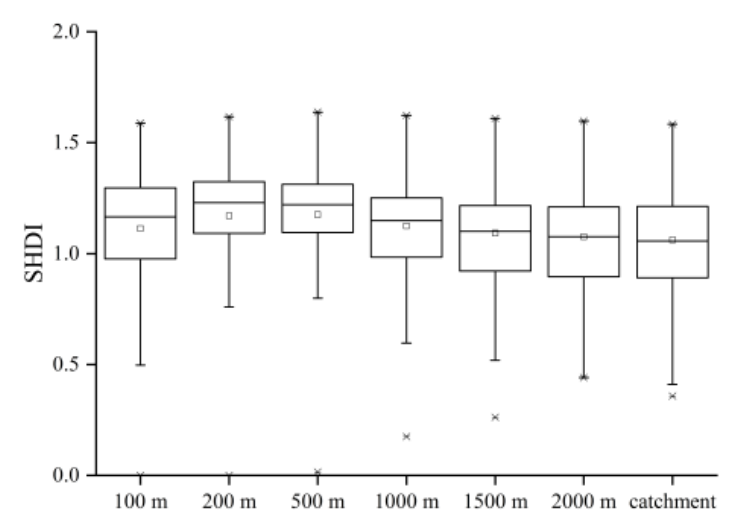

(d)

Figure 3. Land use metrics representing the spatial configurations of the riparian buffer widths and catchment: (a) PD means the number of patches per unit area (number per $100 \mathrm{ha}$ ); (b) LSI provides a standardized measure of total edge or edge density that adjusts for the size of the landscape; (c) CONTAG describes the degree of agglomeration or spreading trend of different patch types in the landscape; (d) SHDI equals minus the sum, across all patch types, of the proportional abundance of each patch type multiplied by that proportion.

\subsection{Relationship between Land Use and Water Quality at Multiple Scales}

Based on stepwise regression to screen significant explanatory variables (Table 2), the forward selection method in the RDA process was used to filter out the dominant land use variable groups $(p<0.05)$, and the relationship between land-use variables and water quality was visually shown through an ordination diagram (Figure 5). Table 3 was the explanatory ability of different spatial scales, which showed the land-use variables selected for the catchment and each buffer width explained $29.8 \%$ to $35.7 \%$ of the changes in water quality. Although the explanatory ability of the $1000 \mathrm{~m}$ buffer was the largest (35.7\%), the difference in the explanatory ability of the catchment and the $200 \mathrm{~m}$ buffer was only $1.9 \%$ and $2.5 \%$, respectively.

Table 2. Significant explanatory variables screened out by stepwise regression analysis.

\begin{tabular}{|c|c|c|}
\hline Scales & & Explanatory Variables \\
\hline \multirow{6}{*}{$\begin{array}{l}\text { Riparian buffer } \\
\text { width }\end{array}$} & $100 \mathrm{~m}$ & $\begin{array}{l}\text { PLANDcul, PDcul, LSIcul, PDwoo, PLANDshr, LSIshr, } \\
\text { PLANDgra, AIgra, LSIgra, PDgra, PLANDbui }\end{array}$ \\
\hline & $200 \mathrm{~m}$ & $\begin{array}{l}\text { PLANDcul, LPIcul, PDwoo, AIwoo, AIshr, PDshr, } \\
\text { AIgra, LSIgra, LSIbui, PLANDbui, PDbui }\end{array}$ \\
\hline & $500 \mathrm{~m}$ & $\begin{array}{c}\text { LSIcul, PDwoo, PLANDshr, LSIshr, LPIgra, LSIgra, } \\
\text { AIgra, AIbui, PLANDbui }\end{array}$ \\
\hline & $1000 \mathrm{~m}$ & $\begin{array}{l}\text { PLANDcul, LSIcul, LSIwoo, PLANDwoo, PDwoo, } \\
\text { PLANDshr, AIshr, LPIgra, AIgra, AIbui, PLANDbui }\end{array}$ \\
\hline & $1500 \mathrm{~m}$ & $\begin{array}{l}\text { LSIcul, LSIwoo, PDwoo, PLANDshr, LSIshr, AIgra, } \\
\text { LPIgra, PLANDbui, AIbui, PDbui }\end{array}$ \\
\hline & $2000 \mathrm{~m}$ & $\begin{array}{l}\text { LSIcul, PLANDwoo, PDwoo, PLANDshr, LSIgra, } \\
\text { AIgra, PDgra, PLANDbui }\end{array}$ \\
\hline \multicolumn{2}{|l|}{ Catchment } & $\begin{array}{l}\text { LSIcul, PLANDwoo, LSIwoo, PLANDshr, AIgra, } \\
\text { PDgra, LSIgra, PDbui, PLANDbui }\end{array}$ \\
\hline
\end{tabular}



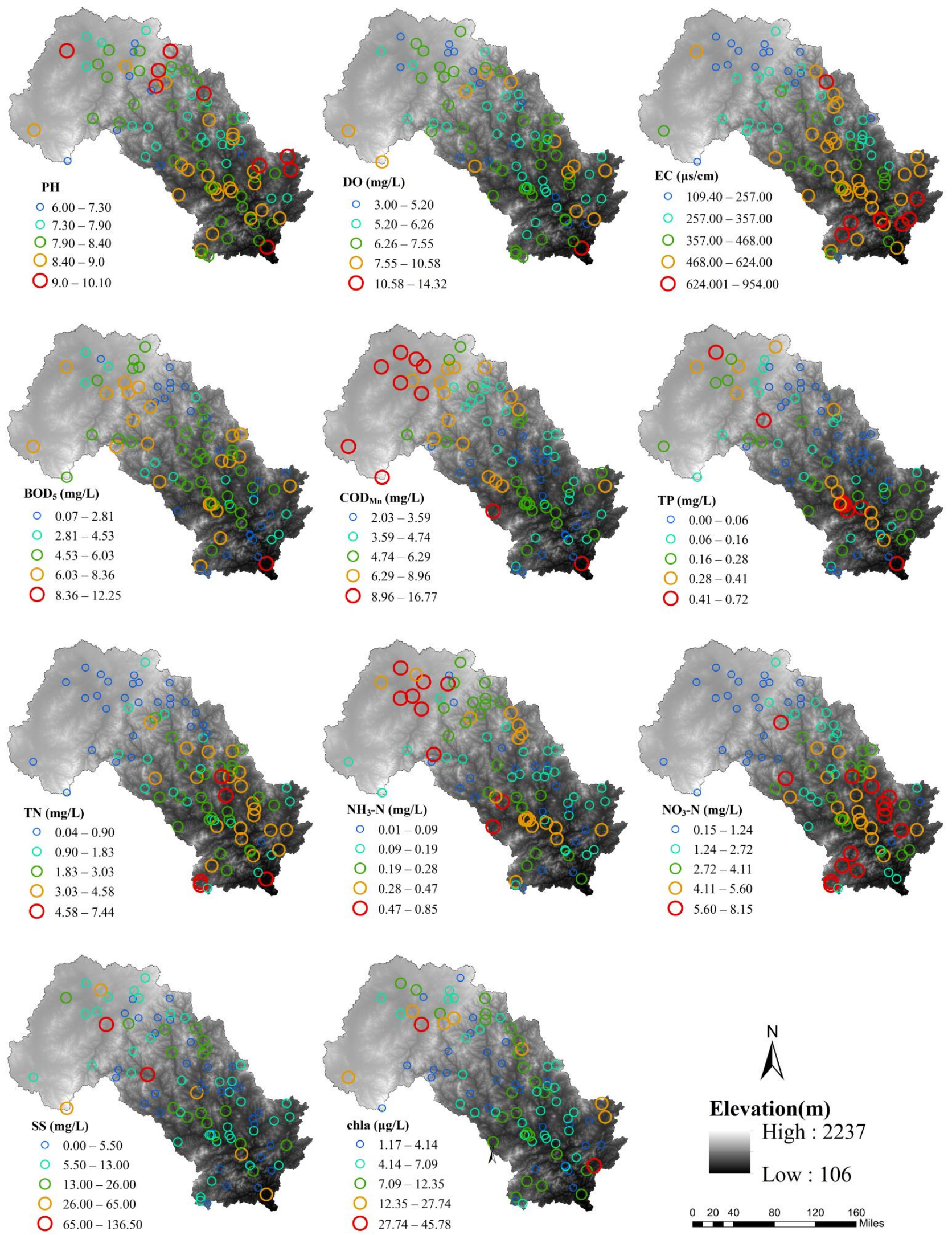

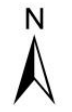

\section{Elevation(m)}

High : 2237

Low : 106

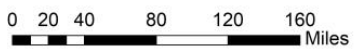

Figure 4. The spatial variations in the water quality parameters in the Luanhe River basin. 
Table 3. RDA ranking axes and the total variance explanatory rate at each buffer width and catchment scale.

\begin{tabular}{|c|c|c|c|c|c|c|}
\hline \multicolumn{2}{|c|}{ Scales } & Axis 1 & Axis 2 & Axis 3 & Axis 4 & $\begin{array}{c}\text { Explained } \\
\text { Variance }(\%)\end{array}$ \\
\hline \multirow{18}{*}{$\begin{array}{c}\text { Riparian } \\
\text { buffer width }\end{array}$} & $100 \mathrm{~m}$ & & & & & \\
\hline & $\mathrm{EV}$ & 0.205 & 0.076 & 0.013 & 0.002 & 29.8 \\
\hline & CPC (\%) & 68.87 & 94.47 & 98.87 & 99.55 & \\
\hline & $200 \mathrm{~m}$ & & & & & \\
\hline & EV & 0.212 & 0.086 & 0.011 & 0.003 & 33.8 \\
\hline & CPC (\%) & 67.56 & 95.17 & 98.75 & 99.58 & \\
\hline & $500 \mathrm{~m}$ & & & & & \\
\hline & EV & 0.222 & 0.097 & 0.0009 & 0.005 & 33.5 \\
\hline & CPC (\%) & 66.18 & 95.26 & 98.02 & 99.54 & \\
\hline & $1000 \mathrm{~m}$ & & & & & \\
\hline & EV & 0.234 & 0.109 & 0.009 & 0.004 & 35.7 \\
\hline & СРС (\%) & 65.45 & 95.89 & 98.46 & 99.56 & \\
\hline & $1500 \mathrm{~m}$ & & & & & \\
\hline & EV & 0.233 & 0.098 & 0.011 & 0.011 & 35.6 \\
\hline & CPC (\%) & 65.53 & 92.90 & 96.09 & 99.19 & \\
\hline & $2000 \mathrm{~m}$ & & & & & \\
\hline & EV & 0.220 & 0.090 & 0.019 & 0.003 & 33.4 \\
\hline & СРC (\%) & 65.82 & 92.81 & 98.52 & 99.54 & \\
\hline \multirow{2}{*}{ Catchment } & EV & 0.212 & 0.097 & 0.017 & 0.005 & 33.2 \\
\hline & CPC (\%) & 63.80 & 92.85 & 98.02 & 99.57 & \\
\hline
\end{tabular}

Notes: "EV" is the abbreviation for "Eigen values", "CPC (\%)" is the abbreviation for "Cumulative percentage correlation of land use-water quality variable $(\%) "$.

Figure 5 showed that $\mathrm{TN}, \mathrm{NO}_{3}-\mathrm{N}, \mathrm{COD}_{\mathrm{Mn}}, \mathrm{TP}$, and $\mathrm{SS}$ had significant relationships with the land-use variables. Among them, $\mathrm{TN}$ and $\mathrm{NO}_{3}-\mathrm{N}$ were positively correlated with PDcul and PDshr in the $100 \mathrm{~m}$ and $200 \mathrm{~m}$ buffers, respectively, and were negatively correlated with AIgra. At the 500-2000 m buffer and the catchment scale, TN and $\mathrm{NO}_{3}-\mathrm{N}$ were mainly positively correlated with PLANDshr and PDwoo. $\mathrm{COD}_{\mathrm{Mn}}$ had a significant positive correlation with AIgra and a negative correlation with PDwoo at the catchment scale and for almost all buffers. TP and SS were mainly positively correlated with LSIshr and PLANDbui at the catchment scale and for almost all buffers. The relationships between other water quality parameters and land-use variables were not obvious.

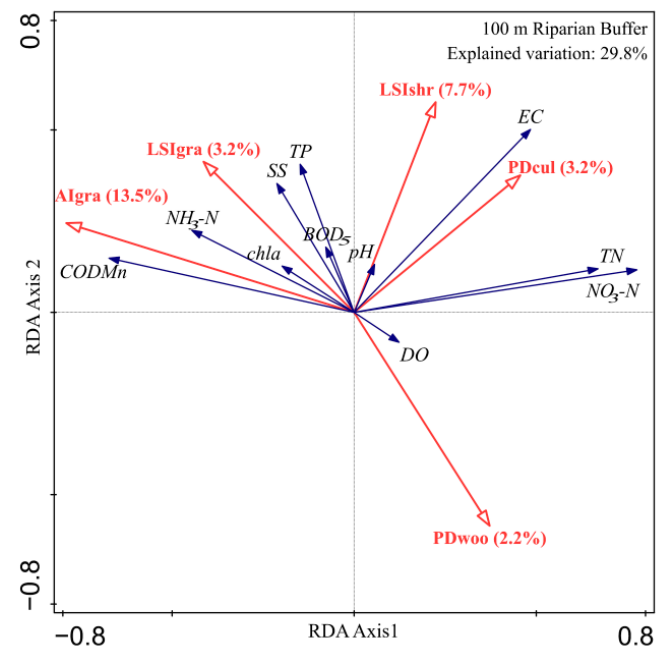

(a)

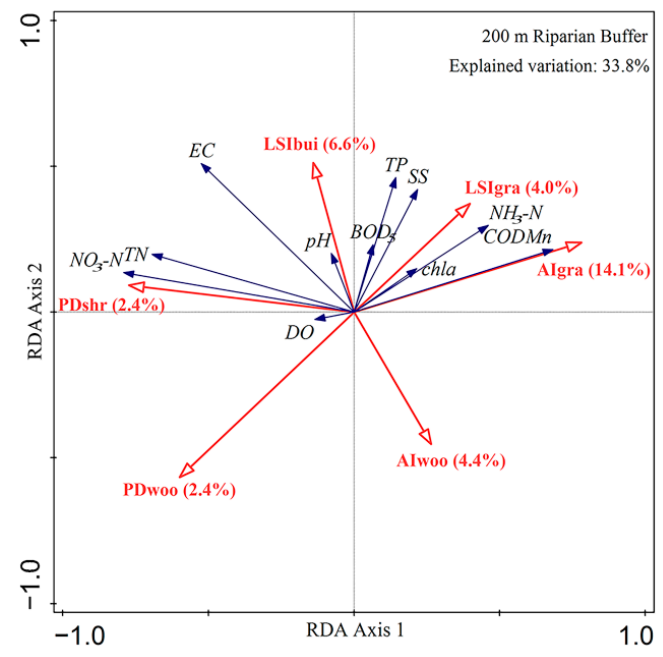

(b)

Figure 5. Cont. 


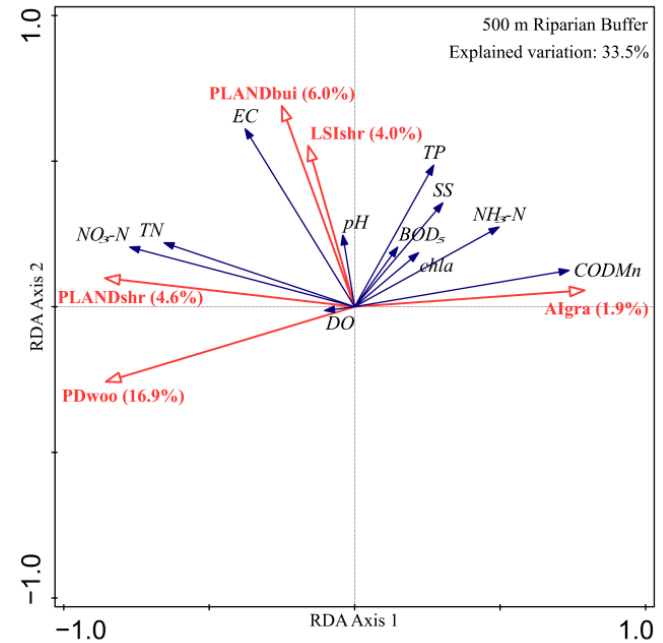

(c)

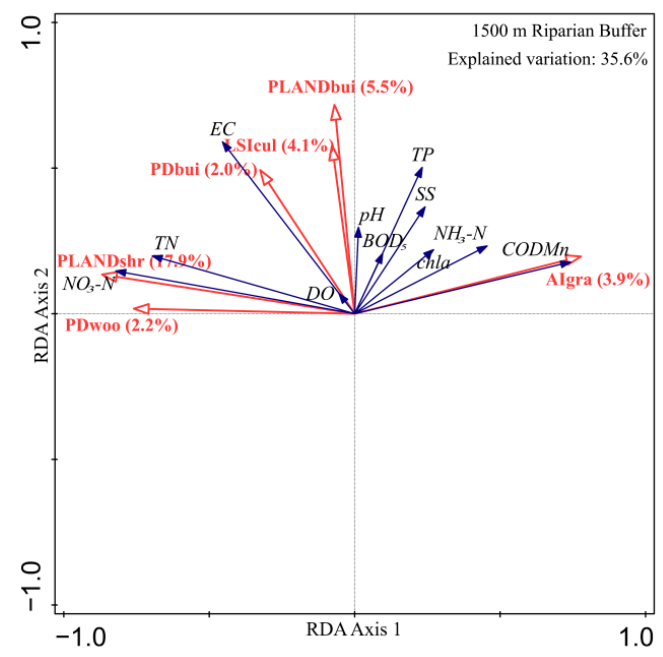

(e)

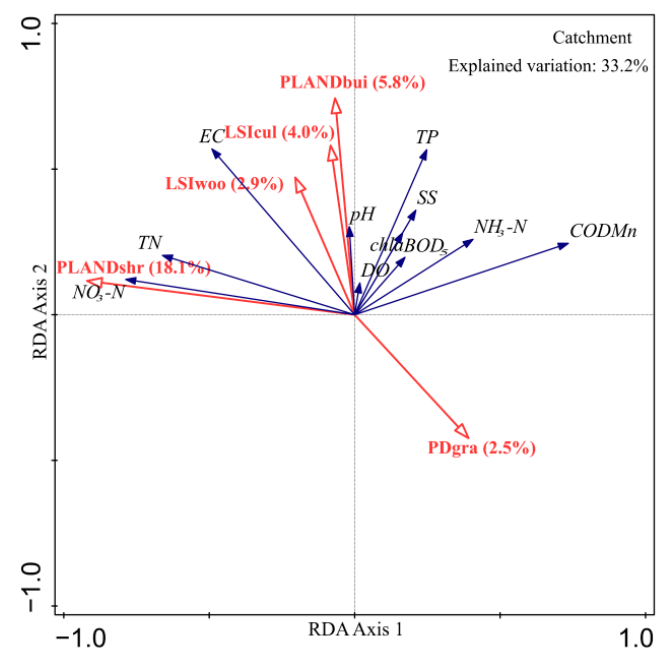

(g)

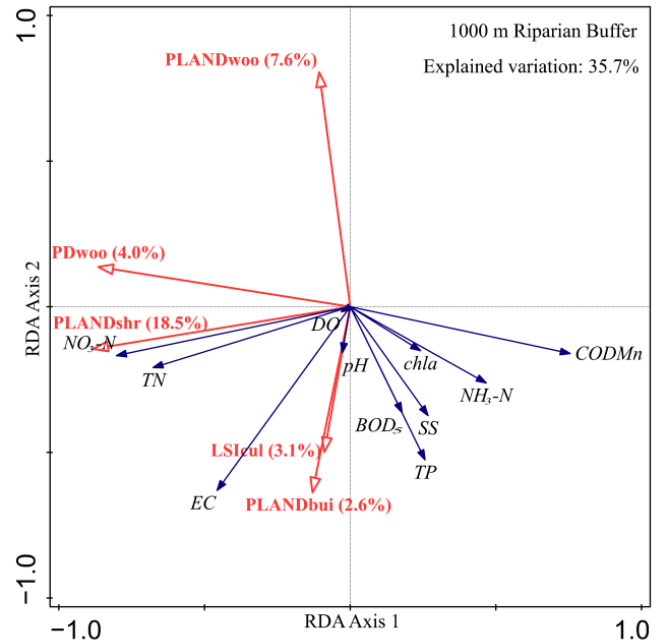

(d)

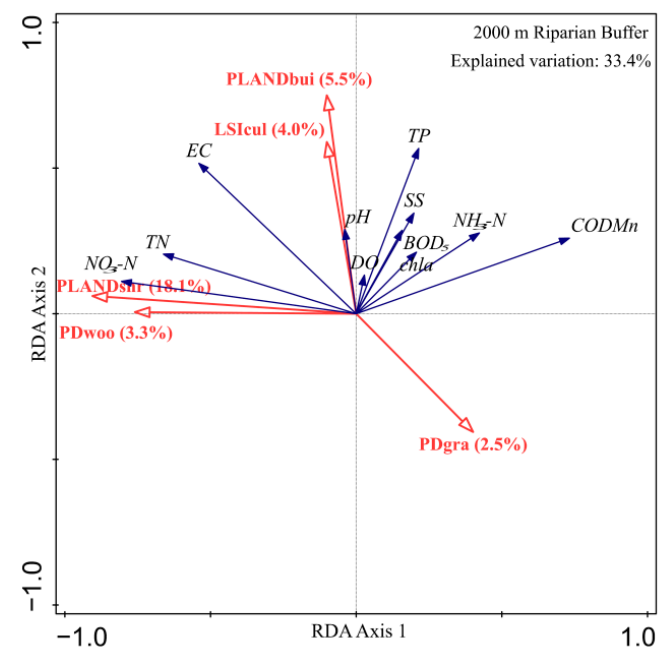

(f)

Figure 5. Redundancy analysis (RDA) biplots showing the correlation between water quality variables (black arrows) and land use variables (red arrows). (a-f) respectively represent the scale of a riparian buffer with different widths (100 $\mathrm{m}$, $200 \mathrm{~m}, 500 \mathrm{~m}, 1000 \mathrm{~m}, 1500 \mathrm{~m}$, and $2000 \mathrm{~m}$ ), and (g) represents catchment scale. 


\subsection{Differences in the Capability of Land Use Composition and Configuration to Explain Water Quality at Different Scales}

Based on the RDA of the water quality differences explained by the land-use variables, we further used VPA to distinguish the respective explanatory ability of land use composition and configuration. The results (Figure 6) showed that at the catchment scale and for all buffer widths, the shared ability of land use composition and configuration to interpret water quality was greater than that of each individually, and the explanatory ability of land use configuration was greater than that of land use composition.

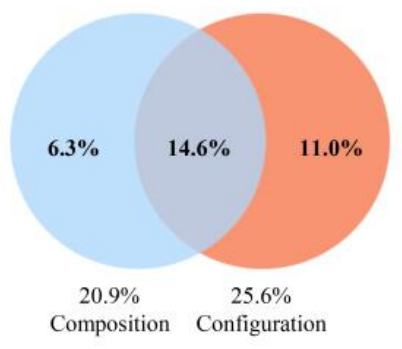

$100 \mathrm{~m}$

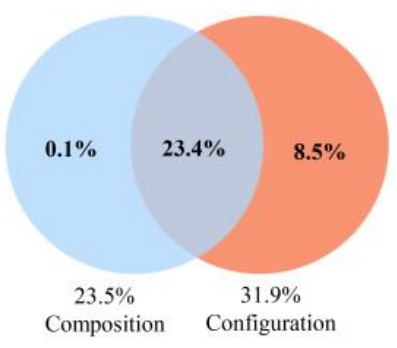

$1500 \mathrm{~m}$

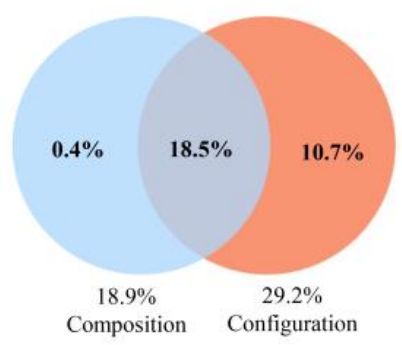

$200 \mathrm{~m}$

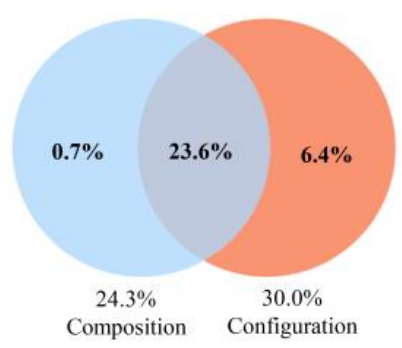

$2000 \mathrm{~m}$

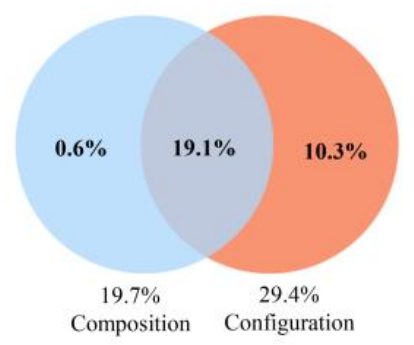

$500 \mathrm{~m}$

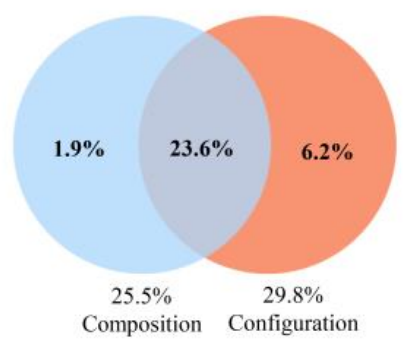

Catchment

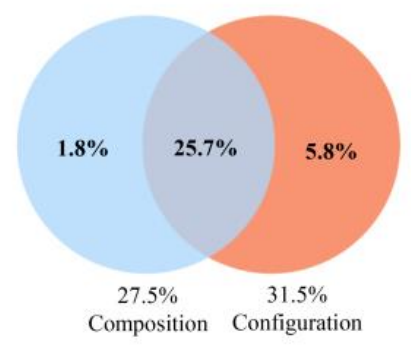

$1000 \mathrm{~m}$

Figure 6. Fractions of the variation explained by individual and joint effects of the land use composition and configuration.

In terms of the change trends at spatial scales, the individual explanatory ability of the land-use composition and configuration in the $100 \mathrm{~m}$ buffer was the largest. With increasing buffer width, the individual explanatory ability of the land-use composition ranged from $0.1 \%$ to $1.9 \%$. The range of individual explanatory abilities was $5.8-10.7 \%$, and the overall trend decreased. Additionally, the joint explanatory ability of land use composition and configuration in the 100-1000 m buffer widths showed a gradual increase and remained stable when the buffer exceeded $1000 \mathrm{~m}$.

\section{Discussion}

\subsection{Effective Spatial Scale Identification of Land Use Patterns on Water Quality}

Different from conclusions in previous studies $[5,7,19]$, the RDA results showed that there is little difference in the ability to explain water quality changes between the catchment and the buffer zone with different widths (Figure 5). However, it is worth noting that the explanatory rate of the RDA results has its own complex rules, and its ability to analyze the impact of land use and water quality is limited. Specifically, in our study area, in the near-distance riparian buffer widths (e.g., within 100 and $200 \mathrm{~m}$ ), grassland, built-up land, and cultivated land had a strong ability to explain water quality changes, and shrubland and woodland became the main land use variables to explain water quality changes as the width of the buffer increased. This result was largely due to fertilizer, livestock manure, and domestic sewage from farmlands or urban areas more easily entering the river within these areas [44,45]. The impact of buffer areas far away from water bodies on water quality may be more complicated [13]. The land use in the basin is dominated by shrubland and woodland, their slopes are relatively large, and the 
corresponding soils are mostly brown earth and cinnamon soils (Table 1). This soil has poor anti-corrosion ability and is more prone to soil erosion, which makes it easier for nitrogen, phosphorus, and other nutrients to enter water bodies through surface runoff [13]. Given this scenario, we should accurately understand the multi-spatial scale relationship between land use and water quality and should not take the explanatory rate as the only basis for the impact of land use on water quality, and we should also pay attention to identifying which land-use variables contribute to the explanatory rate.

Furthermore, the VPA results showed that the ability of land use composition and configuration to jointly explain water quality changes at different scales was greater than the individual ability of these two factors (Figure 6); this result indicates that there was collinearity between the land use composition and configuration and that the joint influence of the two was an important reason for the variation in the water quality, which is consistent with existing views [13]. Therefore, we need to understand the impact of land-use composition and configuration at different spatial scales on water quality changes from a holistic perspective instead of focusing at a certain scale in isolation.

\subsection{Main Land-Use Variables That Affect Water Quality at Different Spatial Scales}

The RDA results show that $\mathrm{TN}$ and $\mathrm{NO}_{3}-\mathrm{N}$ were positively correlated with PDcul and PDshr in the riparian buffer zone within $200 \mathrm{~m}$ of the water bodies, and this result may have been related to agricultural nonpoint source pollution [46]. We know that summer is a critical period for crop growth, when the frequency of fertilization increases and the surface runoff is relatively high, which makes it easier for nutrients such as nitrogen and phosphorus to migrate into water bodies [47]. In addition, the fragmentation of forests is not conducive to the filtration and retention of pollutants [48], which is also an important reason for this correlation. It is worth noting that there was a very significant positive correlation between $\mathrm{TN}, \mathrm{NO}_{3}-\mathrm{N}$, and PLANDshr in the buffer beyond $200 \mathrm{~m}$ and at the catchment scale. This result is different from the conclusion that forestland is generally regarded as a medium that can intercept pollutants and improve water quality [49]. The reason for this result is that on the one hand, it may be related to the classification of land use types [14]. When we interpreted land use types, the orchards and traditional Chinese medicine plantations may have been classified into the shrubland category due to the constraints on satellite image resolution. Fertilization during the planting of orchards and Chinese medicinal materials increases the nitrogen content of the soil. On the other hand, the average slope of the shrubland was the largest among all land use types (Table 1), which was conducive to soil erosion after rainfall and accelerated the flow of fertilizer into the river [50].

In addition, $\mathrm{TN}$ and $\mathrm{NO}_{3}-\mathrm{N}$ were negatively correlated with AIgra in the buffer close to the water bodies, which was generally confirmed by existing studies that show that grassland has a purifying effect on water quality. In addition, $C O D_{M n}$ was positively correlated with AIgra at all scales, which may have been caused by the high humus in the grassland on the Bashang Plateau [33] and may also have been related to the enhanced control of dominant land-use types (grassland) in the overall landscape [40].

TP and SS were positively correlated with PLANDbui at almost all scales, which is consistent with the positive correlation between built-up land and river water quality degradation $[47,51,52]$. The built-up land in the study area is mainly distributed near water, and the lack of effective treatment of the large amount of surface debris produced by resident life increases the concentration of TP and SS [53]. Additionally, the increase in impervious surface area (ISA) in the process of urbanization made it impossible for natural vegetation and soil to filter and intercept pollutants [54].

\subsection{Implications for Management}

Improving river water quality is a complex and long process that requires continuous control and intervention by managers [31,55]. In contrast to the results of some studies that focus on land use management, our results mainly focus on improving water quality by 
rationally optimizing the composition and configuration of land use at different spatial scales [56]. This approach calls for managers to focus on planning the configuration of natural forests and grasslands in the riparian zone in a scientific way to reduce vegetation fragmentation $[57,58]$. Furthermore, attention must be paid to the control of agricultural nonpoint source pollution [59], and cultivated land should be moved away from the buffer zones close to water bodies under the premise of ensuring that the total area of the cultivated land in the region remains unchanged [60,61].

At the catchment scale and for the buffer areas far away from the water bodies, especially in hilly areas with large slopes, more attention should be given to protecting natural woodlands and shrublands and increasing the ratio of woodland and grassland area to ensure the healthy development of the aquatic environment.

\section{Conclusions}

Based on the results of the relationship between river water quality and land-use variables, we found that there was little difference in the ability of the riparian zone and the catchment scale to explain water quality changes. Cultivated land, built-up land, and shrubland were the main factors that influenced the increase in the concentrations of TN, $\mathrm{NO}_{3}-\mathrm{N}, \mathrm{TP}$, and SS in the river. The good connectivity of the grasslands accounted for the high $\mathrm{COD}_{\mathrm{Mn}}$. The joint explanatory ability of land use composition and configuration was greater than their separate explanatory ability, and the closer to the water bodies, the more obvious the land-use configuration role was. With the increase in the width of the buffer, the impact of land-use composition on water quality gradually increased.

Our research results support that water quality management is a comprehensive problem that requires overall consideration and attention in local areas. The results provide a scientific basis for river water ecological management. Although nonpoint source pollution is generally more serious in summer than in other seasons, only sampling water quality in summer may have concealed some information caused by seasonal differences. In future work, we will collect water quality data in different seasons to further explore whether seasonal changes in the study area will affect the relationship between land use and water quality.

Author Contributions: Conceptualization, M.S. and Q.L.; Methodology, M.S. and M.K.; Software, M.S.; Validation, M.S. and Y.J.; Formal analysis, M.S.; Investigation, M.S., Y.T., Y.L. and X.X.; Data Curation, M.S. and Y.J.; Writing-Original Draft Preparation, M.S.; Writing-Review \& Editing, M.S.; Visualization, M.S.; Supervision, Y.J.; Project Administration, Y.J.; Funding Acquisition, Y.J. All authors have read and agreed to the published version of the manuscript.

Funding: This research was funded by the National Science and Technology Major Project: Water Pollution Control and Management Technology of China, grant number No. 2017ZX07301-001-03 and the APC was funded by the National Science and Technology Major Project: Water Pollution Control and Management Technology of China, grant number No. 2017ZX07301-001-03.

Institutional Review Board Statement: Not applicable.

Informed Consent Statement: Not applicable.

Data Availability Statement: The data presented in this study are available on request from the corresponding author.

Acknowledgments: This work was supported by the National Science and Technology Major Project: Water Pollution Control and Management Technology of China (No. 2017ZX07301-001-03). We would like to thanks the anonymous reviewers for their contributions.

Conflicts of Interest: The authors declare no conflict of interest. 


\section{References}

1. Vörösmarty, C.J.; McIntyre, P.B.; Gessner, M.O.; Dudgeon, D.; Prusevich, A.; Green, P.; Davies, P.M. Global threats to human water security and river biodiversity. Nature 2010, 467, 555-561. [CrossRef]

2. Feld, C.K.; Fernandes, M.R.; Ferreira, M.T.; Hering, D.; Ormerod, S.J.; Venohr, M.; Gutiérrez-Cánovas, C. Evaluating riparian solutions to multiple stressor problems in river ecosystems-a conceptual study. Water Res. 2018, 139, 381-394. [CrossRef] [PubMed]

3. Liu, Q.; Tian, Y.; Liu, Y.; Yu, M.; Hou, Z.; He, K.; Jiang, Y. Relationship between dissolved organic matter and phytoplankton community dynamics in a human-impacted subtropical river. J. Clean. Prod. 2021, 289, 125-144. [CrossRef]

4. Tu, J. Spatially varying relationships between land use and water quality across an urbanization gradient explored by geographically weighted regression. Appl. Geogr. 2011, 31, 376-392. [CrossRef]

5. Mainali, J.; Chang, H. Landscape and anthropogenic factors affecting spatial patterns of water quality trends in a large river basin, South Korea. J. Hydrol. 2018, 564, 26-40. [CrossRef]

6. Barbosa, A.E.; Fernandes, J.N.; David, L.M. Key issues for sustainable urban stormwater management. Water Res. 2012, 46, 6787-6798. [CrossRef]

7. Sun, Y.; Guo, Q.; Liu, J.; Wang, R. Scale effects on spatially varying relationships between urban landscape patterns and water quality. Environ. Manag. 2014, 54, 272-287. [CrossRef]

8. Nafi'Shehab, Z.; Jamil, N.R.; Aris, A.Z.; Shafie, N.S. Spatial variation impact of landscape patterns and land use on water quality across an urbanized watershed in Bentong, Malaysia. Ecol. Indic. 2021, 122, 107254. [CrossRef]

9. Franco, E.G. The Global Risks Report 2020. In World Economic Forum. 2020. Available online: https://www.weforum.org/ reports / the-global-risks-report-2020 (accessed on 28 January 2020).

10. Sliva, L.; Williams, D.D. Buffer zone versus whole catchment approaches to studying land use impact on river water quality. Water Res. 2001, 35, 3462-3472. [CrossRef]

11. Shi, P.; Zhang, Y.; Li, Z.; Li, P.; Xu, G. Influence of land use and land cover patterns on seasonal water quality at multi-spatial scales. Catena 2017, 151, 182-190. [CrossRef]

12. Hille, S.; Andersen, D.K.; Kronvang, B.; Baattrup-Pedersen, A. Structural and functional characteristics of buffer strip vegetation in an agricultural landscape-high potential for nutrient removal but low potential for plant biodiversity. Sci. Total Environ. 2018, 628, 805-814. [CrossRef]

13. Ding, J.; Jiang, Y.; Liu, Q.; Hou, Z.; Liao, J.; Fu, L.; Peng, Q. Influences of the land use pattern on water quality in low-order streams of the Dongjiang River basin, China: A multi-scale analysis. Sci. Total Environ. 2016, 551, 205-216. [CrossRef] [PubMed]

14. Xu, Q.; Wang, P.; Shu, W.; Ding, M.; Zhang, H. Influence of landscape structures on river water quality at multiple spatial scales: A case study of the Yuan river watershed, China. Ecol. Indic. 2021, 121, 107226. [CrossRef]

15. Amuchástegui, G.; Di Franco, L.; Feijoó, C. Catchment morphometric characteristics, land use and water chemistry in Pampean streams: A regional approach. Hydrobiologia 2016, 767, 65-79. [CrossRef]

16. Leal, C.G.; Barlow, J.; Gardner, T.A.; Hughes, R.M.; Leitão, R.P.; Mac Nally, R.; Pompeu, P.S. Is environmental legislation conserving tropical stream faunas? A large-scale assessment of local, riparian and catchment-scale influences on Amazonian fish J. Appl. Ecol. 2018, 55, 1312-1326. [CrossRef] [PubMed]

17. Meixler, M.S.; Bain, M.B. Landscape scale assessment of stream channel and riparian habitat restoration needs. Landsc. Ecol. Eng. 2010, 6, 235-245. [CrossRef]

18. Dosskey, M.G.; Vidon, P.; Gurwick, N.P.; Allan, C.J.; Duval, T.P.; Lowrance, R. The role of riparian vegetation in protecting and improving chemical water quality in streams 1. J. Am. Water Resour. Assoc. 2010, 46, 261-277. [CrossRef]

19. Li, K.; Chi, G.; Wang, L.; Xie, Y.; Wang, X.; Fan, Z. Identifying the critical riparian buffer zone with the strongest linkage between landscape characteristics and surface water quality. Ecol. Indic. 2018, 93, 741-752. [CrossRef]

20. Xiao, R.; Wang, G.; Zhang, Q.; Zhang, Z. Multi-scale analysis of relationship between landscape pattern and urban river water quality in different seasons. Sci. Rep. 2016, 6, 25250. [CrossRef]

21. Zhang, J.; Li, S.; Dong, R.; Jiang, C.; Ni, M. Influences of land use metrics at multi-spatial scales on seasonal water quality: A case study of river systems in the Three Gorges Reservoir Area, China. J. Clean. Prod. 2019, 206, 76-85. [CrossRef]

22. Gove, N.E.; Edwards, R.T.; Conquest, L.L. Effects of scale on land use and water quality relationships: A longitudinal basin-wide perspective 1. J. Am. Water Resour. Assoc. 2001, 37, 1721-1734. [CrossRef]

23. Mitchell, M.G.; Bennett, E.M.; Gonzalez, A. Linking landscape connectivity and ecosystem service provision: Current knowledge and research gaps. Ecosystems 2013, 16, 894-908. [CrossRef]

24. Clément, F.; Ruiz, J.; Rodríguez, M.A.; Blais, D.; Campeau, S. Landscape diversity and forest edge density regulate stream water quality in agricultural catchments. Ecol. Indic. 2017, 72, 627-639. [CrossRef]

25. McGarigal, K.; Marks, B.J. Spatial Pattern Analysis Program for Quantifying Landscape Structure; Gen. Tech. Rep. PNW-GTR-351; US Department of Agriculture, Forest Service, Pacific Northwest Research Station: Portland, OR, USA, $1995 ;$ pp. 1-122.

26. Ricart, A.M.; Dalmau, A.; Pérez, M.; Romero, J. Effects of landscape configuration on the exchange of materials in seagrass ecosystems. Mar. Ecol. Prog. Ser. 2015, 532, 89-100. [CrossRef]

27. Shen, Z.; Hou, X.; Li, W.; Aini, G. Relating landscape characteristics to non-point source pollution in a typical urbanized watershed in the municipality of Beijing. Landsc. Urban Plan. 2014, 123, 96-107. [CrossRef] 
28. Uuemaa, E.; Antrop, M.; Roosaare, J.; Marja, R.; Mander, Ü. Landscape metrics and indices: An overview of their use in landscape research. Living Rev. Landsc. Res. 2009, 3, 1-28. Available online: http:/ / hdl.handle.net/1854/LU-695518 (accessed on 9 June 2018). [CrossRef]

29. Uuemaa, E.; Mander, Ü.; Marja, R. Trends in the use of landscape spatial metrics as landscape indicators: A review. Ecol. Indic. 2013, 28, 100-106. [CrossRef]

30. Zhang, G.; Guhathakurta, S.; Dai, G.; Wu, L.; Yan, L. The control of land-use patterns for stormwater management at multiple spatial scales. Environ. Manag. 2013, 51, 555-570. [CrossRef]

31. Liu, J.; Liu, X.; Wang, Y.; Li, Y.; Jiang, Y.; Fu, Y.; Wu, J. Landscape composition or configuration: Which contributes more to catchment hydrological flows and variations? Landsc. Ecol. 2020, 35, 1531-1551. [CrossRef]

32. Cheng, X.; Chen, L.; Sun, R. Modeling the non-point source pollution risks by combing pollutant sources, precipitation, and landscape structure. Environ. Sci. Pollut. R. 2019, 26, 11856-11863. [CrossRef]

33. Tian, Y.; Jiang, Y.; Liu, Q.; Dong, M.; Xu, D.; Liu, Y.; Xu, X. Using a water quality index to assess the water quality of the upper and middle streams of the Luanhe River, northern China. Sci. Total Environ. 2019, 667, 142-151. [CrossRef]

34. Hebei Province Bureau of Statistics. Hebei Province Statistical Yearbook 2017; China Statistics Press: Beijing, China, 2017.

35. Inner Mongolia Autonomous Region Bureau of Statistics. Inner Mongolia Autonomous Region Statistical Yearbook 2017; China Statistics Press: Beijing, China, 2017.

36. State Environmental Protection Administration. The National Standards of the People's Republic of China: Environmental Quality Standards for Surface Water (GB 3838-2002); Chinese Environmental Sciences Press: Beijing, China, 2002.

37. Arnold, J.G.; Srinivasan, R.; Muttiah, R.S.; Williams, J.R. Large area hydrologic modeling and assessment part I: Model development 1. J. Am. Water Resour. Assoc. 1998, 34, 73-89. [CrossRef]

38. Alberti, M.; Booth, D.; Hill, K.; Coburn, B.; Avolio, C.; Coe, S.; Spirandelli, D. The impact of urban patterns on aquatic ecosystems: An empirical analysis in Puget lowland sub-basins. Landsc. Urban Plan. 2007, 80, 345-361. [CrossRef]

39. Kupfer, J.A. Landscape ecology and biogeography: Rethinking landscape metrics in a post-FRAGSTATS landscape. Prog. Phys. Geogr. 2012, 36, 400-420. [CrossRef]

40. McGarigal, K.; Cushman, S.A.; Ene, E. FRAGSTATS v4: Spatial Pattern Analysis Program for Categorical and Continuous Maps. Computer Software Program Produced by the Authors at the University of Massachusetts, Amherst. 2012. Available online: http:/ / www.umass.edu/landeco/research/fragstats/fragstats.html (accessed on 8 June 2018).

41. Braak, C.J.; Smilauer, P. Canoco Reference Manual and User's Guide: Software for Ordination, Version 5.0. Ithaca USA: Microcomputer Power; Wageningen University: Wageningen, The Netherlands, 2012; p. 496.

42. Jongman, E.; Jongman, S.R.R. Data Analysis in Community and Landscape Ecology; Cambridge University Press: Cambridge, UK, 1995. Available online: www.cambridge.org/9780521475747 (accessed on 8 June 2018).

43. Økland, R.H.; Eilertsen, O. Canonical correspondence analysis with variation partitioning: Some comments and an application. J. Veg. Sci. 1994, 5, 117-126. [CrossRef]

44. de Mello, K.; Valente, R.A.; Randhir, T.O.; dos Santos, A.C.A.; Vettorazzi, C.A. Effects of land use and land cover on water quality of low-order streams in Southeastern Brazil: Watershed versus riparian zone. Catena 2018, 167, 130-138. [CrossRef]

45. Bawa, R.; Dwivedi, P. Impact of land cover on groundwater quality in the Upper Floridan Aquifer in Florida, United States. Environ. Pollut. 2019, 252, 1828-1840. [CrossRef] [PubMed]

46. Guo, Q.; Ma, K.; Yang, L.; He, K. Testing a Dynamic Complex Hypothesis in the Analysis of Land Use Impact on Lake Water Quality. Water Resour. Manag. 2010, 24, 1313-1332. [CrossRef]

47. Ouyang, W.; Skidmore, A.K.; Toxopeus, A.G.; Hao, F. Long-term vegetation landscape pattern with non-point source nutrient pollution in upper stream of Yellow River basin. J. Hydrol. 2010, 389, 373-380. [CrossRef]

48. Haidary, A.; Amiri, B.J.; Adamowski, J.; Fohrer, N.; Nakane, K. Assessing the impacts of four land use types on the water quality of wetlands in Japan. Water Resour. Manag. 2013, 27, 2217-2229. [CrossRef]

49. Pacheco, F.A.L.; Santos, R.M.B.; Fernandes, L.S.; Pereira, M.G.; Cortes, R.M.V. Controls and forecasts of nitrate yields in forested watersheds: A view over mainland Portugal. Sci. Total Environ. 2015, 537, 421-440. [CrossRef]

50. Ahearn, D.S.; Sheibley, R.W.; Dahlgren, R.A.; Anderson, M.; Johnson, J.; Tate, K.W. Land use and land cover influence on water quality in the last free-flowing river draining the western Sierra Nevada, California. J. Hydrol. 2005, 313, 234-247. [CrossRef]

51. Lee, S.W.; Hwang, S.J.; Lee, S.B.; Hwang, H.S.; Sung, H.C. Landscape ecological approach to the relationships of land use patterns in watersheds to water quality characteristics. Landsc. Urban Plan. 2009, 92, 80-89. [CrossRef]

52. Kennen, J.G.; Riva-Murray, K.; Beaulieu, K.M. Determining hydrologic factors that influence stream macroinvertebrate assemblages in the northeastern US. Ecohydrol. Ecosyst. Land Water Process Interact. Ecohydrogeomorphology 2010, 3, 88-106. [CrossRef]

53. Namugize, J.N.; Jewitt, G.; Graham, M. Effects of land use and land cover changes on water quality in the uMngeni river catchment, South Africa. Phys. Chem. Earth Parts A B C 2018, 105, 247-264. [CrossRef]

54. Jackson, C.R.; Bahn, R.A.; Webster, J.R. Water quality signals from rural land use and exurbanization in a mountain landscape: What's clear and what's confounded? J. Am. Water Resour. Assoc. 2017, 53, 1212-1228. [CrossRef]

55. Ding, J.; Jiang, Y.; Fu, L.; Liu, Q.; Peng, Q.; Kang, M. Impacts of land use on surface water quality in a subtropical River Basin: A case study of the Dongjiang River Basin, Southeastern China. Water 2015, 7, 4427-4445. [CrossRef]

56. Tudesque, L.; Tisseuil, C.; Lek, S. Scale-dependent effects of land cover on water physico-chemistry and diatom-based metrics in a major river system, the Adour-Garonne basin (South Western France). Sci. Total Environ. 2014, 466, 47-55. [CrossRef] 
57. Amiri, B.J.; Nakane, K. Modeling the linkage between river water quality and landscape metrics in the Chugoku District of Japan. Water Resour. Manag. 2009, 23, 931-956. [CrossRef]

58. Ai, L.; Shi, Z.H.; Yin, W.; Huang, X. Spatial and seasonal patterns in stream water contamination across mountainous watersheds: Linkage with landscape characteristics. J. Hydrol. 2015, 523, 398-408. [CrossRef]

59. Mokarram, M.; Saber, A.; Sheykhi, V. Effects of heavy metal contamination on river water quality due to release of industrial effluents. J. Clean. Prod. 2020, 277, 123380. [CrossRef]

60. Fernandes, J.D.F.; de Souza, A.L.; Tanaka, M.O. Can the structure of a riparian forest remnant influence stream water quality? A tropical case study. Hydrobiologia 2014, 724, 175-185. [CrossRef]

61. Gu, Q.; Hu, H.; Ma, L.; Sheng, L.; Yang, S.; Zhang, X.; Chen, L. Characterizing the spatial variations of the relationship between land use and surface water quality using self-organizing map approach. Ecol. Indic. 2019, 102, 633-643. [CrossRef] 